\title{
Apparent photosynthesis of terrestrial mosses: An indicator of population functional health
}

Dale H. Vitt

Apparent photosynthesis of terrestrial mosses: An indicator of population functional health. - Acta Mus. Siles. Sci. Natur., 68: 45-52, 2019.

\begin{abstract}
Terrestrial mosses dominate the ground in many vegetation types and most are long-lived perennials with highly complex canopies. Long-term population health continues through numerous wetting and drying cycles; however, extreme drought or extended wet periods may create conditions that cause some parts of the population to die or remain inactive. I examined apparent photosynthesis of fully hydrated populations of four terrestrial species of mosses occurring in leaf-free mesohabitats in temperate deciduous forests of eastern North America in order to explore photosynthetic variability of both popula-tions and species. There was high variability in rates of apparent photosynthesis among the popula-tions of mosses for all four species examined in this study. Despite this variability within species, all four species achieved similar mean rates of photosynthesis. Two years after relocation to nearly bare ground habitats, populations of three of the four species achieved similar apparent photosynthetic rates as natural popula-tions, and functioned in a similar manner.
\end{abstract}

Key words: Apparent photosynthesis, Bryoandersonia illecebra, deciduous forest, moss, Thuidium delicatulum

\section{Introduction}

Bryophytes can form a dominant component of the terrestrial landscape in a number of vegetation types. For example, coniferous boreal forests have ground layers of a nearly continuous cover of feather mosses (Bonan \& Shugart 1989; Esseen et al. 1997). Both minerogenous acidic (poor) fens and ombrogenous bogs have ground layers of $80-100 \%$ cover of Sphagnum mosses, while calcareous rich fens are dominated by a number of species of true mosses (Gorham \& Janssens 1992; Vitt 2000; Wheeler \& Proctor 2002). Higher elevation sitetypes in tropical areas can have ground layers with high cover (Richards 1984; Vitt 1991), as well as temperate rain forests at low elevations (DeLucia et al. 2014). Also, early successional stages of lava flows can have $100 \%$ cover of mosses in cool mesic climates such as those found in Iceland (Fig. 1) and higher elevations on the Hawaiian Islands. Temperate forests dominated by deciduous trees also have a rich flora of terrestrial bryophytes, but these are usually restricted in occurrence to areas where leaf litter is limited (Loeske 1901; Startsev et al. 2008, Fig. 2). In most of these situations, bryophytes can play a significant role in the moisture regime and carbon and nitrogen budgets of the ecosystem (Goulden \& Crill 1997; DeLuca et al. 2002; Bond-Lamberty et al. 2004).

Like vascular plants, bryophytes have complex canopies with abundant leaves that provide the structure for photosynthesis. Also, like many vascular plants, many bryophytes are longlived perennials with strong support mechanisms contained in the branches and stems. Unlike vascu-lar plants, bryophytes are poikilohydric and have little ability to control water loss. The small size of bryophytes provides for high ratios of surface area to volume that means that they dry out quickly (Proctor et al. 2007) - as a result, metabolic activity, especially gas exchange is limited by water availability (reviewed by Vitt et al. 2014). As drying occurs, photosynthesis decreases and individual species each have different drying curve times. In most terrestrial 
habitats mosses may spend a majority of their time dry and inactive and achieve maximum photosynthetic rates only when fully hydrated. Although overall long-term population health may continue with normal wetting and drying times, extreme drought or extended wet periods may create conditions that cause some parts of the population to die (Proctor et al. 2007). In these cases, populations may persist for some time, yet remain only partially healthy and active, with individual stems and/or leaves non-functional.
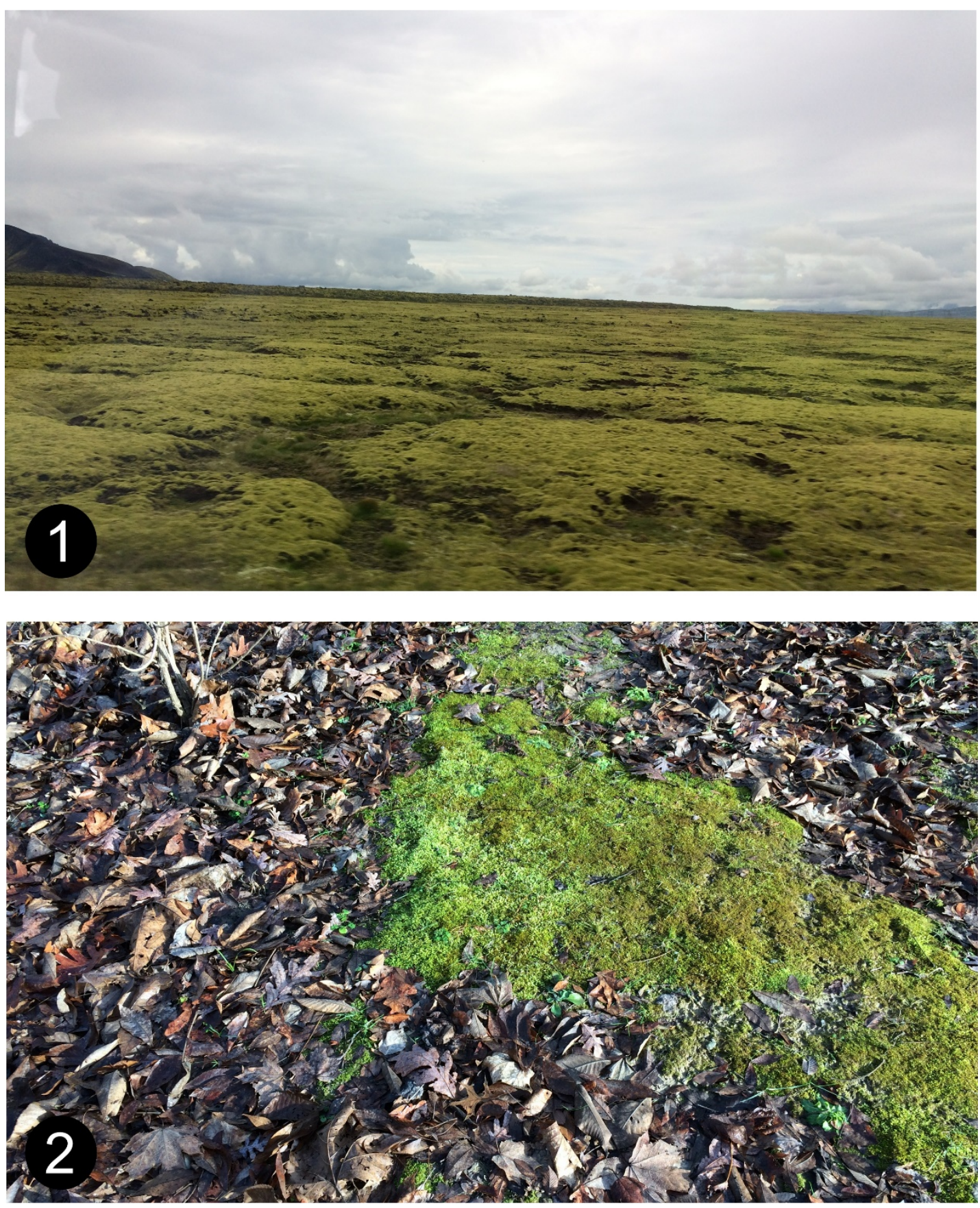

Figs 1-2: Photographs of terrestrial moss habitats. 1 - Racomitrium lanuginosum dominating old lava flows occurring near Nesjavellir Power Plant, southeastern Iceland. 2 - Oxyrrhynchium hians and Haplocladium microphyllum occurring in leaf-free areas of a temperate deciduous forest (Illinois, U.S.A.). 
Carbon fixation is determined by the maximum rate of photosynthesis when the bryophyte canopy is fully hydrated and the rate of photosynthesis that is associated with the individual species drying curves. Previous studies have in general, demonstrated in the laboratory that rates of photosynthesis of bryophytes are similar to those of vascular plants when based on chlorophyll contents (Martin \& Adamson 2001). Other studies, (e.g., Wang et al. 2017) have extracted individual plants or the green portions of individual plants from bryophyte populations and measured photosynthesis under fully hydrated conditions in the laboratory and report data on a mass basis. However, studies that examine rates of photosynthesis of natural populations are rare. Under natural conditions, undisturbed bryophyte populations consist of three dimensional canopies of overlapping leaves containing chlorophyll, along with structural components of stems, branches, and rhizoids without chlorophyll. From an ecosystem perspective, it is important to know the extent that natural populations are healthy and actively sequestering carbon and how this activity varies across a number of populations of the same species occurring in a similar habitat. In this study, I examined rates of photosynthesis achieved in microcosms populated by natural, fully hydrated populations in order to provide an indicator of population health and how it compares across a number of mono-specific populations. I asked two questions: 1) Do different species of mosses have similar apparent photosynthetic rates when fully hydrated and 2) How do the carbon flux rates of these populations vary when fully hydrated?

Many mosses, including many terrestrial species, interact and receive moisture mostly (or only) from the atmosphere, rather than from the substrate (Busby et al. 1978; Vitt \& Glime 1984). These mosses have complex canopies and structural features that enable hydration and water retention with little interaction with the underlying substrate. However as far as I am aware it is not known if when removed from the the substrate and relocated to a nearby locality with similar substrate if 3 ) these populations continue to have similar carbon flux rates and 4) if the relocated populations function similar to the original ones?

\section{Study Areas}

Forested watersheds along two headwater streams, one in Fairfax County, Virginia (38 40"22"N; $\left.77^{\circ} 12^{\prime} 07^{\prime} \mathrm{W}\right)$ and one in McDonough County, Illinois $\left(40^{\circ} 25^{\prime} 55^{\prime} \mathrm{N}\right.$; 90 $\left.93^{\circ} 35^{\prime} \mathrm{W}\right)$, were sampled for moss populations occurring on terrestrial, exposed micro-sites, especially frequent along the banks of small streams (Fig. 3). Both study areas are located in largely undisturbed, mature, eastern deciduous, temperate forests. In Virginia, the dominant tree species is Fagus grandifolia, along with Liquidambar styraciflua, Liriodendron tulipifera, Fraxinus spp., Carya alba, Acer saccharum, and Quercus prinus, with a sparse understory of Ilex opaca. In Illinois the dominant tree species are Quercus alba, Q. rubra, Q. velutina, Tilia americana, Carya spp., and Platanus occidentalis. Bryophytes occur on exposed micro-sites where leaf litter is reduced due to slightly higher elevations and proximity to streams with less canopy cover (Vitt et al. 2018). At the Virginia site, Thuidium delicatulum and Bryoandersonia illecebra are abundant, while at the Illinois site, Plagiomnium cuspidatum and Oxyrrhynchium hians are the most abundant species. Site characteristics and a list of bryophytes found in the research plots are in Vitt et al. (2018). Climate of the two study areas is similar, with long-term annual precipitation and mean annual temperature varying from $97 \mathrm{~cm}$ and $14.5^{\circ} \mathrm{C}$ (Illinois) to $101 \mathrm{~cm}$ and $9.9^{\circ} \mathrm{C}$ (Virginia), respectively.

\section{Methods}

At each study area, 28 patches of bryophytes on stream banks were selected, with each site about 30-50 m apart. At each site and within well-established natural moss populations, a $158 \mathrm{~cm}^{2}$ circular plot was established and permanently marked by a sharpened circular plastic sleeve (Figs. 4-5). In October of 2015, a second $158 \mathrm{~cm}^{2}$ circular plug was removed from the natural population and relocated to nearby bare soil (Figs. 6-8). Over the course of two years (October 2015-October 2017) plots were monitored and their fate recorded each spring and fall. During this time period, some of the natural populations and relocated samples were lost to erosion or stochastic events (e.g., limb and tree fall) as well as leaf litter cover for the relocated populations. For the purposes of this study and when feasible, during the first year these lost plots were replaced with plots from nearby natural populations or extracted and placed in the same location as the earlier relocated sample. After two years and in 
October 2017, 42 samples from the Virginia study area and 29 samples from Illinois study area were gently lifted from the underlying mineral soil and transported to the laboratory.

In the field, the individual moss samples were collected in $81 \mathrm{~cm}^{2}$ petri dishes, closed with tape, and transported to the laboratory, sprayed until saturated with deionized water and left for 30 minutes for surface water to evaporate, and placed in a chamber $\left(158 \mathrm{~cm}^{2}\right.$ area with a volume of $\left.1,100 \mathrm{~mL}\right)$. These microcosms were maintained at $20^{\circ} \mathrm{C}$ and provided with $1,000 \mathrm{mmol} \mathrm{m}^{-2} \mathrm{sec}^{-1}$ light covering the photosynthetic spectrum (CI 301 LA light source). $\mathrm{CO}_{2}$ flux was measured using a PP Systems Model EGM-4 IRGA. Microcosms were left for 15 min to equilibrate before flux measurements and $\mathrm{CO}_{2}$ flux recorded after an additional 5 min. Rates are here reported as apparent photosynthesis - defined as the rate of photosynthesis less the rate of photorespiration (Wohlfahrt \& Gu 2015).
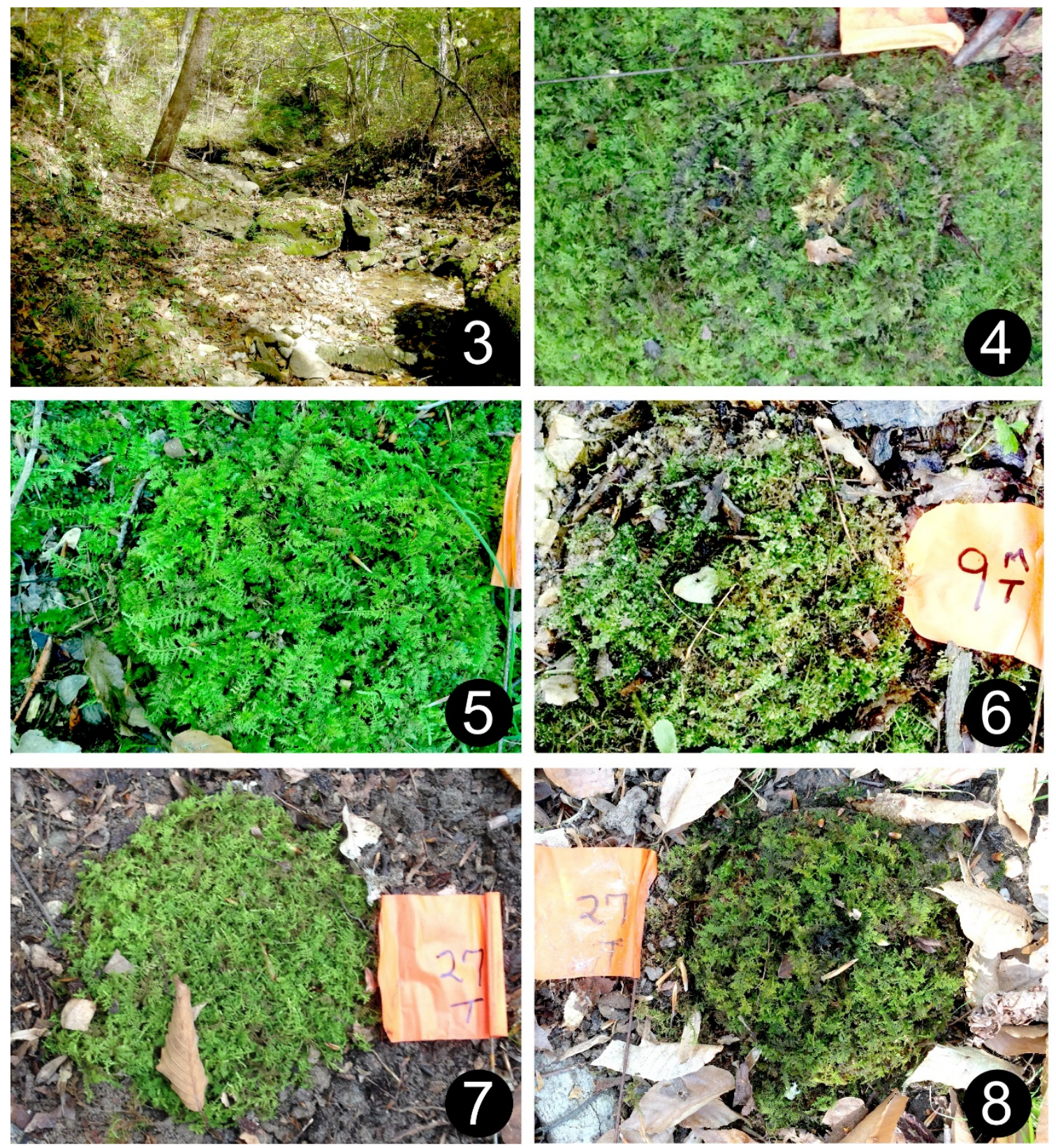

Figs 3-8: Photographs of one study area and various plot types. 3 - Typical forest along stream in Illinois. Photo taken October 2017. 4 - Natural population of Thuidium delicatulum (Virginia) with a few shoots dry (center) among the remaining wet population. Photo taken May 2017. 5 - Natural population of Plagiomnium cuspidatum (Illinois). Photo taken May 2017. 6 - Transplant population of Plagiomnium cuspidatum (Illinois). Photo taken May 2017. 7 - Recent transplant at plot 27 (October 2015) of Thuidium delicatulum (Virginia). Photo taken October 2015. 8 - Transplant population at plot 27 of Thuidium delicatulum (Virginia). Note bark in both Fig. 7 and 8 in lower left of photos. Photo taken October 2017. 


\section{Results}

Site comparisons. In total, we collected and analyzed 42 natural moss populations ( 23 from Virginia and 19 from Illinois) and 29 relocated populations (16 from Virginia and 13 from Illinois). Apparent photosynthesis was not different between the two sites for either the natural populations (t-test: $\mathrm{p}=0.574)$ or the relocated populations ( $\mathrm{t}$-test: $\mathrm{p}=0.192$, Table 1 ) despite the two study sites having very different moss floras. Thirteen moss species occurred in the plots with a total of 38 occurrences at the Virginia study site, with Thuidium delicatulum occurring as the dominant species in $46 \%$ of the plots, and Bryoandersonia illecebra occurred as a dominant in $25 \%$. In comparison, at the Illinois site, 16 moss species occurred in the plots, and in total these occurred 64 times, with Plagiomnium cuspidatum dominant in $36 \%$ of the plots. Oxyrrhynchium (Eurhynchium) hians was found in 10 of the plots (Vitt et al. 2018).

Tab 1: Comparison of mean (S.E.M.) $\mathrm{CO}_{2}$ flux (umol $\mathrm{CO}_{2} \mathrm{~m}^{-2} \mathrm{~s}^{-1}$ ) for microcosms with populations from the two study areas in Fairfax Co., Virginia and McDonough Co., Illinois. Non-significant differences tested with t-test with alpha $<0.05$.

\begin{tabular}{|l|c|c|l|l|}
\hline & Virginia & Illinois & & \\
\hline Natural populations & $1.29[\mathrm{n}=23](0.15)$ & $0.96[\mathrm{n}=19](0.14)$ & $\mathrm{t}=1.61$ & $\mathrm{p}=0.574$ \\
\hline $\begin{array}{l}\text { Relocated } \\
\text { populations }\end{array}$ & $1.25[\mathrm{n}=16](0.17)$ & $1.02[\mathrm{n}=13](0.19)$ & $\mathrm{t}=0.88$ & $\mathrm{p}=0.192$ \\
\hline
\end{tabular}

Species comparisons. We examined fully hydrated apparent photosynthesis for the four most abundant species, Thuidium delicatulum and Bryoandersonia illecebra from the Virginia site and Plagiomnium cuspidatum and Oxyrrhynchium hians from Illinois. Mean apparent photosynthesis ranged from $1.67 \mathrm{umol} \mathrm{CO}_{2} \mathrm{~m}^{-2} \mathrm{~s}^{-1}$ for $B$. illecebra to $0.95 \mathrm{umol} \mathrm{CO}_{2} \mathrm{~m}^{2} \mathrm{~s}^{-1}$ for Plagiomnium cuspidatum; however, apparent photosynthesis for the four species did not differ significantly ( $\mathrm{f}=1.756, \mathrm{p}=0.178$, Fig. 9). Overall, considerable variation was present in the microcosms ranging from 0.57 to $3.03 \mathrm{umol} \mathrm{CO}_{2} \mathrm{~m}^{-2} \mathrm{~s}^{-1}$.

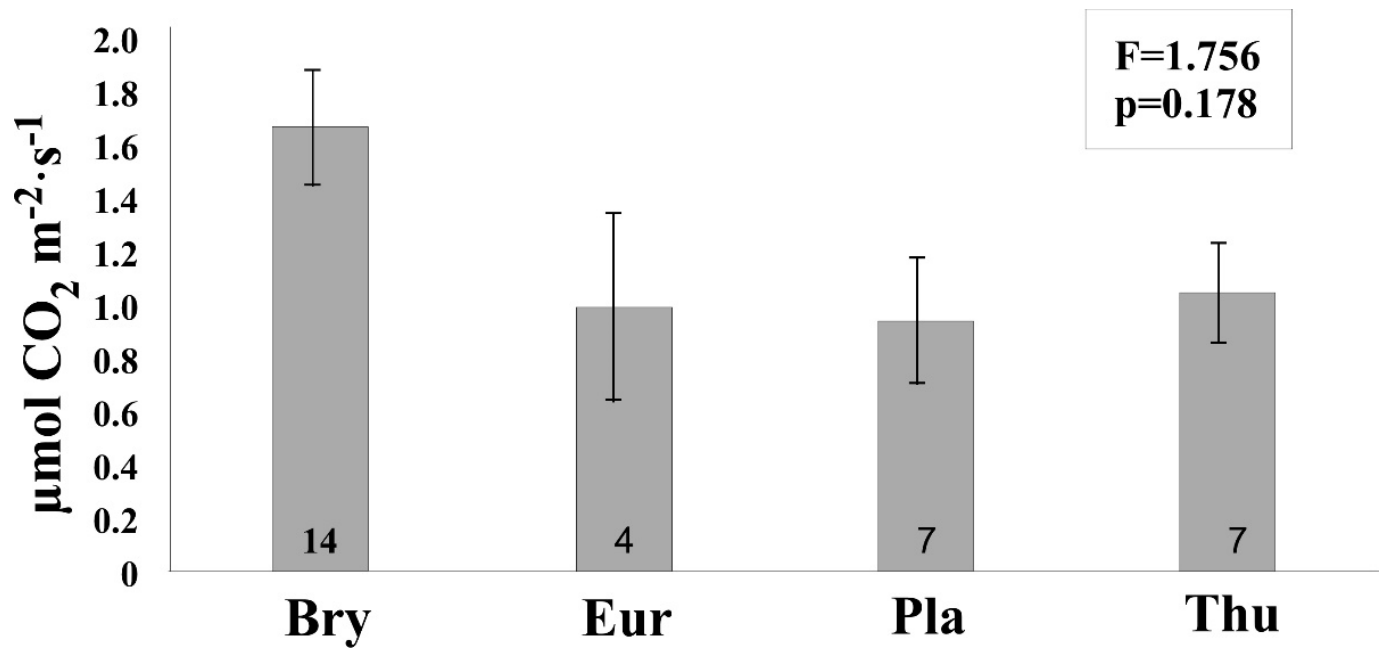

Fig 9: Comparison of $\mathrm{CO}_{2}$ flux within microcosms from natural populations of four moss species (mean \pm S.E.M. with one-way ANOVA). Numbers in bars are number of samples. Bry = Bryoandersonia illecebra, Oxy $=$ Oxyrrhynchium hians, $\mathrm{Pla}=$ Plagiomnium cuspidatum, $\mathrm{Thu}=$ Thuidium delicatulum . 
Relocation comparisons. Microcosms with relocated populations did not differ from those from natural populations for Thuidium delicatulum (t-test: $\mathrm{p}=0.107)$, Oxyrrhynchium hians (t-test: $\mathrm{p}=0.444$ ), and Plagiomnium cuspidatum (t-test: $\mathrm{p}=0.406$ ) with $\mathrm{CO}_{2}$ flux varying from 1.42 umol $\mathrm{CO}_{2} \mathrm{~m}^{-2} \mathrm{sec}^{-1}$ to 0.93 umol $\mathrm{CO}_{2} \mathrm{~m}^{-2} \mathrm{~s}^{-1}$. Apparent photosynthesis for relocated populations was different for Bryoandersonia illecebra (t-test: $\mathrm{p}=0.019)$, with relocated populations about $45 \%$ less than natural populations (Fig. 10).

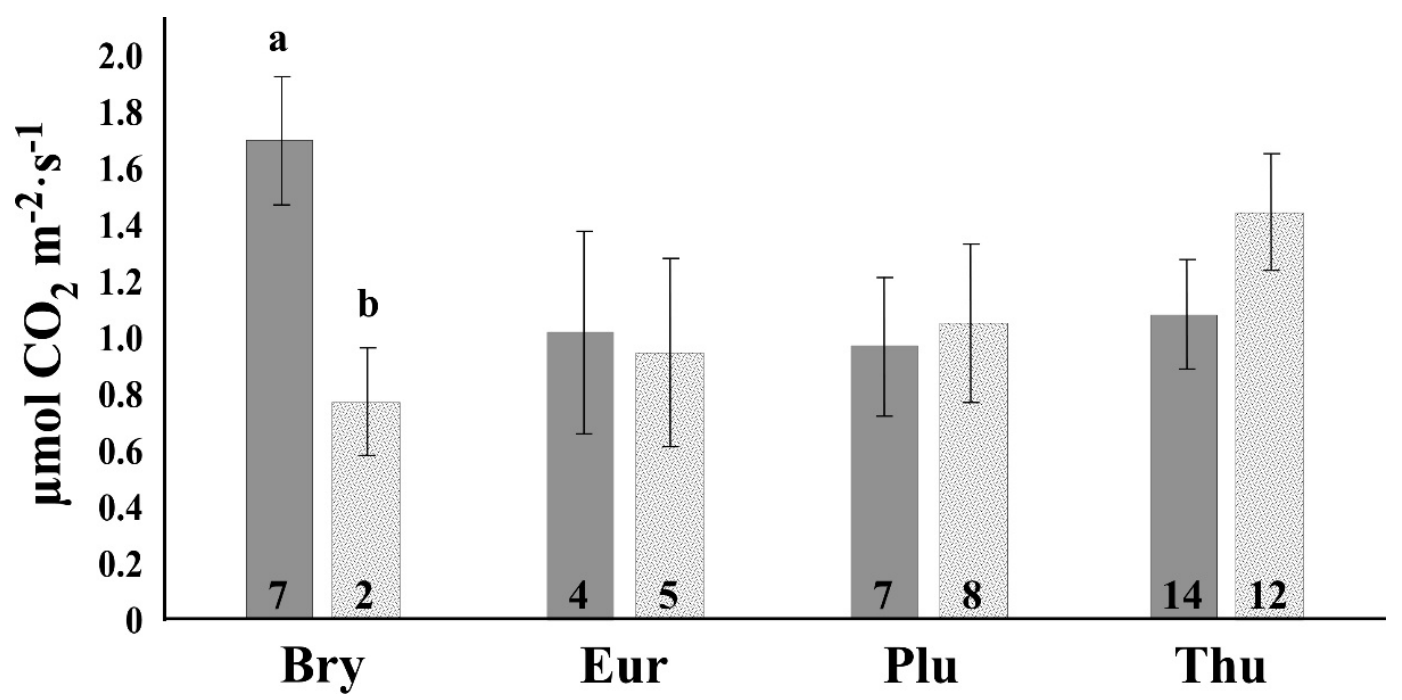

Fig 10: Comparison of $\mathrm{CO}_{2}$ flux from microcosms from natural and relocated populations of four moss species (mean \pm S.E.M.). Different letters indicate significant differences at alpha $<0.05$ (one-way ANOVA for each species calculated separately). Numbers in bars are number of samples. Bry = Bryoandersonia illecebra, Oxy = Oxyrrhynchium hians, $\mathrm{Pla}=$ Plagiomnium cuspidatum, $\mathrm{Thu}=$ Thuidium delicatulum.

\section{Discussion}

Fully hydrated rates of photosynthesis at saturating irradiance for the four moss species were within the ranges usually reported for bryophytes on an area basis (Rice et al. 2008, Waite \& Sack 2010; Wagner et al. 2014; Wang et al. 2014; Liu et al. 2015). Wang et al. 2017 reported a mean of $1.45 \mathrm{umol} \mathrm{CO}_{2} \mathrm{~m}^{-2} \mathrm{~s}^{-1}$ with a range of 0.41 to $7.01 \mathrm{umol} \mathrm{CO}_{2} \mathrm{~m}^{-2} \mathrm{~s}^{-1}$, values that encompass those reported here. Likewise, Delucia et al. (2014), who utilized microcosms similar to those used here, reported somewhat similar values of (gross) photosynthesis and also reported considerable variation in rates of photosynthesis.

Although the mean photosynthetic rate of Bryoandersonia illecebra is considerably higher than the other three species, there are no significant differences between the four species (two from each site) due to the high levels of variation within microcosms for each species. There are several possible reasons for this high variation -1) our methodology for wetting the microcosms did not provide consistent hydration for the moss canopy, 2) natural populations have inherent variability in functioning photosynthetic units, and/or 3) portions of natural populations are variably non-functional (see Fig. 4). It could be that our rehydration procedures (similar to those many others have used, (see DeLucia et al. 2017; Wang et al. 2017) may have led to some small, yet unknown, portion of the variability. It is also possible that there is significant natural variability among moss populations, both in terms of canopy density, amount of living vs. dead stems and leaves, and per cent of functional tissue that are contributing to photosynthesis at any one time. However, despite variable photosynthetic rates, it is remarkable that the four species have similar mean photosynthetic rates and have similar functional contributions to the ecosystem carbon flux. 
The microcosms containing the relocated populations achieved similar photosynthetic rates as the microcosms with natural populations for three of the four species, again with similar variation. The one exception, microcosms with relocated Bryoandersonia illecebra, had significantly lower photosynthetic rates. This species is a relatively large species with loose canopy structure that is easily damaged during the establishment period or to inability to reestablish a cohesive canopy after relocation.

In conclusion, there is high variability in rates of photosynthesis among the populations of mosses that were examined in this study, indicating that overall health of individual populations may also be variable and may be related to recent periods of drying, with severe desiccation periodically damaging the functioning of moss populations (Abel 1956). Despite this variability within species, all four species achieved similar mean rates of photosynthesis. Relocating populations of mosses that are highly dependent on atmospheric inputs suggests that in three of the four species interactions with the underlying mineral soil have little influence on photosynthetic rates.

Acknowledgements: We are grateful to Scott Bradfield and Melissa House for field assistance. Funding for this research was provided by the U.S. National Science Foundation through award 1461773 to R. S. Kang and D. H. Vitt. Thanks to Western Illinois University for granting access to the Ira and Reatha T. Post Wildlife Sanctuary (Illinois) and to the Bureau of Land Management Eastern States for access to the Meadowood Special Recreation Management Area (Virginia).

\section{References}

Abel W.O. (1956): Die Austrocknungsresistenz der Laubmoose. - Oesterreichische Akademie der Wissenschaften, Mathematisch-Naturwissenschaftliche Klasse, Sitzungsberichte, Abteilung 1, 165: 619-707.

Bonan G.B. \& Schugart H.H. (1989): Environmental factors and ecological processes in boreal forests. Annual Reviews in Ecological Systems 20: 1-28.

Bond-Lamberty B., Wang C. \& Gower S.T. (2004): Net primary production and net ecosystem production of a boreal black spruce wildfire chronosequence. - Global Change Biology 10: 473-487.

Busby J.R, Blis s L.C. \& Hamilton C.D. (1978): Microclimate control of growth rates and habitats of the boreal forest mosses, Tomenthypnum nitens and Hylocomium splendens. - Ecological Monographs 48: 95-110.

DeLuca T., Zackrisson H.O., Nilss on M.-C. \& Selstedt A. (2002): Quantifying nitrogen-fixation in feather moss carpets of boreal forests. - Nature 419: 917-920.

DeLucia E.H., Turnbull M.H., Walcroft A.S., Griffin K.L., Tissue D.T., Glenny D., McSeveny T.M. \& Whitehead D. (2003): The contribution of bryophytes to carbon exchange for a temperate forest. - Global Change Biology 9: 2258-2270.

Esseen P.-A., Ehnström B., Ericson L. \& Sjoberg K. (1997): Boreal forests. - Ecological Bulletins 46: 1647.

Gorham E. \& Janssens J. (1992): Concepts of fen and bog reexamined in relation to bryophyte cover and the acidity of surface waters. - Acta Societatis Botanicorum Poloniae 61: 7-20.

Goulden M.L. \& Crill P.M. (1997): Automated measurements of $\mathrm{CO}_{2}$ exchange at the moss surface of a black spruce forest. - Tree Physiology 17: 537-542.

Liu X., Wang Z., Bao W. \& Li X.-M. (2015): Photosynthetic responses of two pleurocarpous mosses to lowlevel nitrogen addition: a study in an oldgrowth fir forest. - Journal of Bryology 37: 15-22.

Loeske L. (1901): Die Moosvereine im Gebiete der Flora von Berlin. - Verhandlungem des Botanischen Vereins für die Provinz Brandenberg 42: 75-164.

Martin C.E. \& Adams on V.J. (2001): Photosynthetic capacity of mosses relative to vascular plants. - Journal of Bryology 23: 319-323.

Proctor M.C.F., Oliver M.J., Wood A.J., et al. (2007): Desiccation-tolerance in bryophytes: A review. - The Bryologist 110: 595-621.

Rice S.K., Aclander L. \& Han son D.T. (2008): Do bryophyte shoot systems function like vascular plant leaves or canopies? Functional trait relationships in Sphagnum mosses (Sphagnaceae). - American Journal of Botany 95: 1366-1374.

Richard s P.W. (1884): Chapter 21. The ecology of tropical forest bryophytes. pp. 1231-1270. In: Schuster R.M. (ed.). New Manual of Bryology. - Hattori Botanical Laboratory, Nichinan, Japan.

Startsev N., Lieffers V.J. \& Landhausser S.M. (2008): Effects of leaf litter on the growth of boreal feather mosses: Implication for forest floor development. - Journal of Vegetation Science 19: 253-260. 
Vitt D.H. (1991): Distribution patterns, adaptive strategies, and morphological changes of mosses along elevational and latitudinal gradients on South Pacific Islands, pp. 205-231. In: Nimis P.-L. \& Crovello T.J. (eds). Quantitative Approaches to Phytogeography. Kluwer Academic Publishers, Dordrecht, The Netherlands.

- (2000): Peatlands: Ecosystems dominated by bryophytes. pp. 312-343. In: Shaw A.J. \& Goffinet B. (eds). Bryophyte Biology. Cambridge University Press, Cambridge.

Vitt D.H. \& Glime J.M. (1984): The structural adaptations of aquatic Musci. - Lindbergia 10: 95-110.

Vitt D.H., Crandall-Stotler B. \& Wood A. (2014): Survival in a dry world through avoidance and tolerance. pp. 267-295. In: Rajakaruna N., Boyd R. \& Harris T. (eds). Plant Ecology and Evolution in Harsh Environments. Nova Publishers.

Vitt D.H., House M. \& Kang R. (2018): The stability of moss populations on stream banks along two firstorder, temperate-forest, headwater streams. - The Bryologist 121: 205-213.

Wagner S., Zotz G. \& Bader M.Y. (2014): The temperature acclimation potential of tropical bryophytes. Plant Biology 16: 117-124.

Waite M. \& Sack L. (2010): How does moss photosynthesis relate to leaf and canopy structure? Trait relationships for 10 Hawaiian species of contrasting light habitats. - New Phytologist 185: 156-172.

Wang Z., B ao W., Feng D. \& Lin H. (2014): Functional trait scaling relationships across 13 temperate mosses growing in wintertime. - Ecological Research 29: 629-639.

Wang Z., Liu X., Bader M.Y., Feng D. \& Bao W. (2017): The 'plant economic spectrum' in bryophytes, a comparative study in subalpine forest. - American Journal of Botany 104: 261-270.

Wheeler B.D. \& Proctor M.C.F. (2002): Ecological gradients, subdivisions and terminology of north-west European mires. - Journal of Ecology 88: 187-203.

Wohlfahrt G. \& Gu L. (2015): The many meanings of gross photosynthesis and their implication for photosynthesis research from leaf to globe. - Plant Cell Environment 38: 2500-2507.

Author' address: Dale H. Vitt, Department of Plant Biology, Southern Illinois University,

Carbondale, IL 62901, U.S.A.

E-mail:dvitt@siu.edu 